\title{
Regulation and Barriers to Trade in Telecommunications Services in the European Union
}

\author{
MARTIN CAVE \\ MATTHEW CORKERY
}

CESIFo WORKING PAPER NO. 2678

CATEgORY 1: Public FinANCE

JUNE 2009

Presented at CESifo Venice Summer Institute 2008

An electronic version of the paper may be downloaded

- from the SSRN website:

- from the RePEc website:

www.SSRN.com

www.RePEc.org

- from the CESifo website:

www.CESifo-group.org/wp 


\title{
Regulation and Barriers to Trade in Telecommunications Services in the European Union
}

\begin{abstract}
Recent advances in telecommunications, particularly using fibre technologies, permit many services based on data-processing to be performed anywhere in the world. They thus become tradable and subject to the laws of comparative advantage. A good example is data-processing within large multi-national corporations, the integrated performance of which can reduce cost and add considerable value. Whereas a single market for the provision of such services has arisen in the US, the equivalent single market in the European Union is impeded by absent or imperfect regulation conducted at the national level, which fails to create a level playing field between the country's former telecommunications monopolist and foreign competitors and prevents the emergence of trade in services, at considerable potential cost to firms operating in the EU. The paper discusses how this problem can be resolved by improved regulatory practice and evaluates the prospects for institutional change, in the form of more centralised scrutiny of regulatory remedies, which would make this more achievable.
\end{abstract}

JEL Code: L5, L9.

\author{
Martin Cave \\ Warwick Business School \\ University of Warwick \\ UK - Coventry, CV4 7AL \\ Martin.Cave@wbs.ac.uk
}

\author{
Matthew Corkery \\ Warwick Business School \\ University of Warwick \\ UK-Coventry, CV4 7AL
}

The authors are extremely grateful for very effective comments from a referee. 


\section{Introduction}

Imagine Idaho were a state in a 27-member 'Second life' union of states of varying sizes. It has its own recently liberalised telecommunications sector, consisting primarily of an historic monopolist whose network is confined to the state; all interstate calls being accomplished via interconnection with another operator.

Telecommunications purchasers in 'Idaho' consist of four categories: households, intrastate businesses, businesses, such as 'Wal-Mart', which operate in other states as well, and firms whose activities girdle the earth (ie embrace multiple federal states), such as Microsoft, BP and Mittal Steel. The requirements of the four categories are different: the first two need little in the way of value-added services; the third and fourth have significant data-processing requirements - which are subject to substantial economies of scale. $^{2}$

How can competition develop, especially for the larger types of customer?

One possible outcome is autarchy. Services for all customers are produced and consumed within the state, in a way which restricts data-processing to a low-scale inefficient operation.

\footnotetext{
${ }^{2}$ We confine ourselves in this paper to discussion of such 'corporate services', but the connection between them and - for example - the provision of telecommunications services to support activities such as banking and gambling is a close one.
} 
A second is 'free trade', by which we mean that services can be produced in one state (the exporter) and consumed in another. ${ }^{3}$ Clearly, each type of customer has a different proportion of services which are tradable. In the case of the first two, it might be a low percentage, confined to customers near the state's borders. In the third and fourth, it might be 50\%. But almost all goods and services exhibit a similar dichotomy of value added into traded (e.g. manufacturing) and non-tradable (e.g. local distribution and retailing).

The third outcome is the construction of non-tariff barriers to trade, implemented via the presence or absence of regulation. The precedents for this being accomplished via positive regulatory intervention are very wide: fears (substantiated or otherwise) about technologies such as GM food; environmental regulations related to carbon-emitting equipment, and so on. But barriers can equally be created by the failure to regulate adequately at state level, possibly by a regulator which is captured by a local incumbent,

Federal authorities may seek to correct such failures. In the 'real' Idaho, this has been accomplished by the principle of federal pre-emption by the FCC. But things are rather different in the only too 'real' European Union, where there are indeed 27 member states of varying sizes each with its own historic monopolist owning a network typically

\footnotetext{
${ }^{3}$ In other words, in the terminology of General Agreements on Trade in Services (Article 1.2) 'the supply of services from the territory of one Member into the territory of any other Member'. Another on the four modes of trade in services is 'by a service supplier of one Member, through commercial presence in the territory of any other Member' - i.e. foreign direct investment. The other two are noted in Section 3 below.
} 
confined to the state's territory, a raft of smaller competitors relying on domestic (or more rarely foreign) direct investment, and its own national regulatory agency. The land areas and populations of the EU and the USA are comparable. European competition law has a 'pre-emption' on matters affecting interstate trade, provided the other conditions for intervention are also fulfilled. But compared with the Single Market of the USA, the EU Single Market in telecommunications services is something of a sham.

The consequences of this might be far-reaching. The deficiencies of European productivity growth when measured by US standards have been analysed in articles with titles such as 'why was Europe left at the station when America's productivity locomotive departed?' (Gordon 2004). Analysis by Bryan Williamson (in Basilisco et al, 2007, Part 2, Ch.4) reviews and analyses the contribution to this differential made by ICT investment. He finds that in the US, overall productivity growth rose dramatically after 1995, with the largest part of the increase attributable to intensive ICT-using private services. In the 15 member states of the European Union in 2004, by contrast, productivity growth fell after 1995, and the contribution of intensive ICT-using private services is about one third of that in the US.

Williamson goes on to speculate about the contribution of networked companies to productivity growth, citing evidence of various kinds that the use of computers and the extent of computer networks are complements - leading to the conclusion that the communications networks which permit the networking play an important role, in conjunction with human capital, in enabling the effective use of ICT investment. The 
communications networks are the indispensable vector of the data, the analysis of which permits the productivity improvement. We seek to analyse this hypothesis below.

Section 2 describes the technological changes which have increased the tradability of, especially, corporate data-processing services carried by communications networks. Section 3 outlines problems in the measurement of trade in telecommunications services. Section 4 discusses the consequences of defective regulation of telecommunications services, while section 5 considers possible institutional remedies affecting regulation.

\section{Defying gravity}

It is commonplace to explain the extent of trade via a gravity model (Krugman and Obstfeld 2006, p.11-17). Newton's law of universal gravitation held that attractive force between two objects was given by the product of their two masses divided by the square of the distance between them, multiplied by the gravitational constant.

Economists are a little less precise, allowing for the volume of trade to be determined by the product of the sizes of the economies, each raised to a power, and divided by the distance between them also raised to a power. The powers and the constant term are estimated from the data, and a bunch of additional factors such as the existence of national boundaries is thrown in too. 
However, in telecommunications, gravity is increasingly being defied as a result of new developments in, especially, long distance communications; in another popular metaphor, we are seeing the death of distance.

Cost structures for fixed telecommunications networks are characterised by:

- Material fixed costs, in both core and access networks; and

- Non-zero marginal costs of service provision.

This is true both for circuit-switched PSTN networks, and also leased line and data networks underpinning the provision of services to corporate clients.

However, network technology developments in recent years - and specifically the use of Internet Protocol (IP) to underpin the deployment of IP-based Next Generation Networks (NGNs) - will play a key role in service provision going forward, both in terms of the breadth of the service portfolio and the underlying costs of service provision.

There is no single, optimal IP-based NGN: the appropriate development and deployment of new networks will depend on a numbers of factors specific to each operator and jurisdiction, such as the business plans of the operator in question, the extent of existing and prospective competition, the performance capabilities of the existing network and the investment required to upgrade or replace. However, in general terms, there are two forms of IP-based network development (for fixed network operators): the core NGN and the access NGN (often referred to as Next Generation Access, or NGA). 
The core NGN involves the replacement of existing core switching and transmission equipment with IP-based routers capable of supporting Voice over IP (VoIP), multimedia and other packetbased services. A key feature is the replacement of the existing plethora of different networks developed to provide different services - leased lines, voice conveyance etc. - with a single multi-service network. This can involve significant rationalisation and simplification of the existing core network structure with deployment of fewer nodes and prospectively fewer points of interconnection (PoIs) with other operators, as well as the distribution of network intelligence (e.g. routing and signalling) towards a core structure of 'soft switches', routers and multi-service access nodes (MSANs) and away from the traditional model characterised by a switching hierarchy with switching elements towards the periphery of the core network. The NGA typically builds on the core NGN principles but extends this to development of the access network to involve investment in deployment of fibre deeper into the access network (for example Fibre to the Node (FttN) or Fibre to the Home (FttH)) in order to provide higher speed access to end users.

Such developments have established a basis for (i) reduction the overall costs of telecoms service provision and (ii) a reduction in the marginal cost of providing call and data services. These cost reductions have resulted from:

- the conveyance efficiency of packet- compared with traditional circuit-switched technology (as well as the IP protocol representing an efficient packet-based solution); and 
- the multi-service nature of NGNs, wherein the previous multiple networks to support a wide range of services - voice, data, etc - are combined into one multi-service network, allowing for increased exploitation of scale and scope economies. ${ }^{4}$

The diagram below describes the changes in cost structures with the deployment of NGNs.

\section{Figure 1}

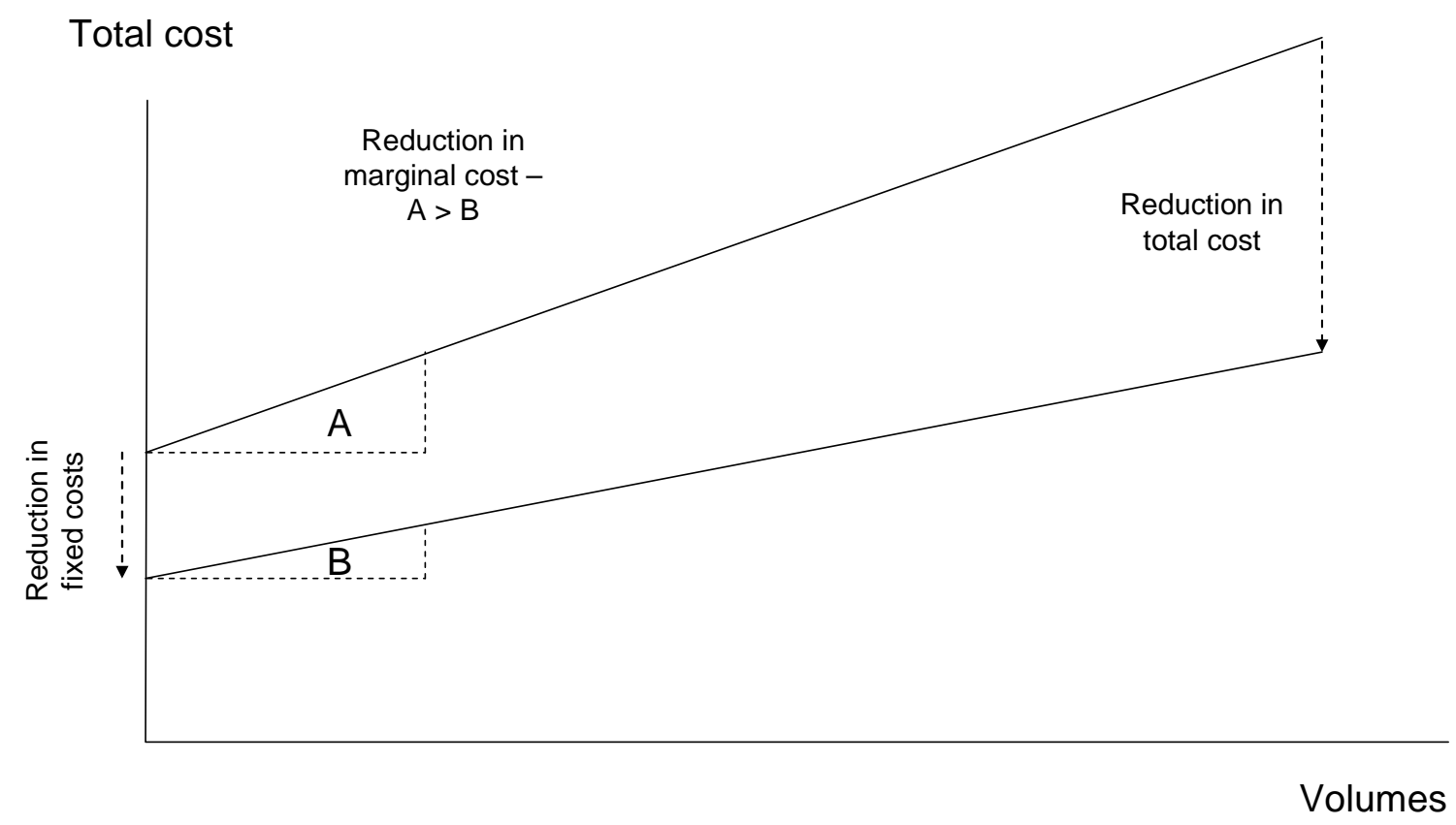

Traditionally, network costs are a function of (i) volume (whether lines, call or data volumes) and (ii) distance. In the context of the deployment of next generation networks, however, there has been much discussion of the 'death of distance', i.e., the tendency of marginal costs to tend to zero (or at least very low levels) such that the costs of traffic conveyance are invariant to the distances over which such traffic is conveyed. Whilst NGN deployment may not represent the

\footnotetext{
${ }^{4}$ For example, BT is in the process of investing 10 billion GBP to replace its existing 17 networks with one multi-service '21 Century Network'.
} 
'death' of distance, it is accepted to provide the ability to reduce the distance-related costs. The consequence of lower (if not zero) distance-related costs is a greater opportunity to exploit the principles of comparative advantage across countries in providing value-added services since the costs of distance represent less of a factor in the costs of production.

There are two fundamental consequences from the above:

1. cross-border trade in value-added services is increasingly viable with reduction in the costs of distance; and

2. such trade will, absent barriers, provide a basis for efficient provision of services, reflecting the comparative advantage of different regions or countries.

Indeed, to the extent that NGNs represent a complete death of distance, value added services will - absent barriers or distortions - be created in the region or country with comparative advantage. And even where NGNs fall short of removing all distance-related costs, they still represent an opportunity for improvement in efficiency since they reduce the extent of comparative advantage or increasing returns to scale required in order to make it worthwhile to provide the value-added element of services in an alternative location. For example, assume with traditional telecoms technology that country $\mathrm{A}$ is able to produce a service at a cost of 100 cents, and that conveyance costs between countries A and B are 20 cents. Under such a scenario, providers of the service in country A would source the service from country B only where country B was able to produce it for 80 cents or less, such that the cost of service from country B including conveyance is below that of production in country A. However, with the introduction of IP-based NGN technology and the consequence reduction in distance-related costs, the 'hurdle' for country B's comparative advantage falls: with the full death of distance, countries $\mathrm{A}$ and $\mathrm{B}$ compete directly in the provision of the service with geographic location being an irrelevance; even with a reduction (but 
no eradication) of distance-related costs, country B needs be more effective at producing the service than country A but not to the same extent at under the original scenario, i.e., under NGN conditions, the distance-related element falls to somewhere between 20 cents and zero; the closer to zero, the more competitive, ceteris paribus, country B becomes.

The prospective ability of NGNs to facilitate greater competition and cross-border trade in valueadded services is significant, both when considering directly the provision of value-added telecommunications services, but also in terms of the role of telecommunications as a facilitator for value creation and economic growth. But, as we have seen, the benefits to end-users are vulnerable to protectionist or inefficient regulation. Before examining this in more detail, it is helpful to look at the data on trade in telecommunications services.

\section{Data on trade in telecommunications services}

Understanding statistics on trade in services is a challenge to which the authors have not yet fully risen. The difficulties arise in part because of the four different modes of supply recognised under the GATS: cross-border trade ('the service crosses the border'), consumption abroad ('the consumer travels'), commercial presence ('direct investment') and presence of natural persons ('an employee or self-employed person visits another country’).

The two categories of trade in services of interest are 'communications services' and 'computer and information services'. The former has two major categories of transactions relating to international communications between residents and non-residents:

- $\quad$ postal and courier services; and 
- telecommunications, or 'the transmission of sound, images and other information by telephone, telex, telegram, radio and television cable and broadcasting, satellite, electronic mail, facsimile services etc., including business network services, teleconferencing and support services. It does not include the value of the information transported. Excluded are ........ and database services and related consumer services to access and manipulate data provided by database services (included in "computer and information services”)' (Manual, 2002, p.40).

The OECD (2007b, Ch.8) also helpfully points out that exports of communications and telecommunications are growing but 'a substantial percentage of traffic cannot be measured if it is carried over leased lines, as such lines do not pass through an international gateway. Moreover, telecommunications services which are transmitted in the form of IP packets sent over the Internet are not included.

Computer information services include (i) computer services; (ii) news agency services; and (iii) other information provision services. 
Our interest lies at the intersection of 'telecommunications' and 'computer services', but unfortunately these two categories are not always adequately distinguished in the data from their larger aggregates of ‘communications’ and ‘computer and information’ services.

By far the largest expansion has occurred in computer and information services - a fifty-fold increase from 1990-2004, achieving a figure of $\$ 140$ bn by 2004 . Over the same period, communications (and telecommunications) services grew approximately five-fold, to \$70bn and \$20bn respectively in 2004.

Among OECD members, the US was the largest importer and exporter of communications services but, in terms of exports as a percentage of GDP it was second lowest (Japan was lowest) in 2004. By that metric (Luxembourg) was the highest by far, followed by Belgium and the Netherlands. The OECD explains Luxembourg's high figure (four times that of its nearest rival) as being caused by 'the size of the banking sector in Luxembourg and the scope of the related information and communications technologies [which] foster extremely intensive ways of outbound telephone service.' [ibid]

It seems that two possible conclusions can be drawn from these data, with difficulties in the way of discriminating between them. Either the data are not reliable, and disguise a large and possibly increasing amount of by-pass of trade statistics - for reasons give above. $\underline{\text { Or the relatively low }}$ growth rates within the OECD of trade in communications services between 1999 and 2004 (a CAGR of $4 \%$ ) suggests the existence of barriers to trade. 


\section{Barriers in trade in telecommunications-based services caused by defective regulation}

As discussed above, telecommunications provide a basis for the exploitation of country or regional advantages in production and the exploitation of comparative advantage and, consequently, economic growth, with the deployment of NGNs increasing the possibility for such. Economic efficiency is key to maximising such effects; where economic efficiency is not attained - either through market failure or through inappropriate or ineffective regulatory intervention - then the ability to generate economic growth through such means is constrained.

At the heart of economic efficiency is the establishment of prices consistent with the efficientlyincurred costs of service provision. Where cross-border trade is required to exploit comparative advantage, the price of non-traded telecommunications conveyance plays an important role in limiting the extent of cross-border trade and by extension, the extent to which comparative advantage can be fully exploited in the interests of economic growth.

International economic law might be able to get a purchase on this problem, for example via the World Trade Organisation (WTO) Annex on Telecommunications and regulatory Refeence Paper - see Kariyawasam (2007). However it is highly unlikely that it can operate at the level of detail necessary to examine and control the price and non-price terms of supply of particular wholesale products. Accordingly the following discussion is based on the application of national sectorspecific telecommunications law and regulation.

Regulatory intervention can take numerous forms, depending on the (prospective) market failure which is being addressed and the nature of the party or parties involved. However, in this 
context, those which are most likely to affect (i) telecommunications sector value add directly and (ii) the extent of cross-border trade - and hence the ability to exploit comparative advantage are:

1. prices in excess of efficient levels (and, by extension, volumes below efficient levels); and

2. lack of supply on the part of (typically) the incumbent operator, thereby constraining output and the ability to optimise use of the telecommunications network.

The 2003 European regulatory framework was established in order to provide greater consistency in policy and regulation across the EU member states. A key characteristic of this framework is the systematic process in specifying regulatory measures. This process is characterised by three distinct phases:

1. market definition, wherein the market under consideration is defined under the principles of competition economics;

2. considering, within the defined market definition, whether an operator (or operators) holds a position of Significant Market Power (SMP) (individually or jointly); and

3. only having established SMP, regulation is then specified in order to address the (prospective) market failures resulting from SMP.

In addition to being required to adhere to this process in establishing regulation, National Regulatory Authorities (NRAs) must choose from a list of possible regulatory measures referred to as 'remedies' - with this list covering a range of measures including (i) mandating access to services and / or facilities and (ii) imposing cost orientation obligations in respect of regulated prices. As a consequence, NRAs have the tools at hand to address the possible 
concerns raised above by establishing regulation which effectively mimics the outcome of a competitive process. However, in practical terms, there exist a number of factors which will impact or constrain the theoretical outcome, including:

1. the status of different players in the market, and the stage of market evolution. An example is the use of glidepaths in setting price controls for regulated services where prices are above cost at the beginning of the regulatory period, with such measures used to prevent shocks to the revenue structure of the operator and achieve a balance between price reductions and financial impacts;

2. information asymmetries, in terms of both available data and capacity of regulatory authorities to analyse and process data in order to arrive at appropriate forms and levels of stringency of regulatory intervention. These are discussed in a trade setting by Martimort and Verdier (2007) who analyse a small open economy upon which is grafted a number of nontradable inputs produced under monopolistic conditions. These markets are subject to regulation by a monopolist which has to 'buy' privately held competition relating to the firms' efficient costs by conceding above-cost prices. As a consequence, the exploitation of comparative advantage changes is reduced in a similar way is it would change of there were the same way that it would if there were no regulation.

3. asymmetric risk, insofar as - in the face of complexity and informational asymmetries - the risk of over-regulating (either in terms of regulating those areas where competition may be effective, or in terms of applying over-stringent regulation, for example in terms of stringency of price controls) may be considered to be more significant than that of under-regulating to the extent that over-regulating may cause financial distress and establish longer-term disincentives to invest, whereas under-regulating may mean prices somewhat higher than otherwise would be the case but a stronger incentive to invest. 
It is important in this context to recognise that an inappropriate absence of regulation - for example where market power is not identified due to absent or incomplete information - may be even more damaging to economic efficiency than sub-optimal regulation, since it potentially provides an opportunity for the dominant operator in question to profit maximise and / or foreclose entry to the detriment of the market and, ultimately, end users.

The diagrams below compare price information across EU member states (European Commission, 2007d and $2008^{5}$ ). The tables show prices for (i) leased circuit local ends, (ii) full unbundled local loop (LLU) and (iii) shared access charges, all of which are used to provide access to networks by incumbent operators. ${ }^{6}$

Figure 2

Monthly rental for leased line $2 \mathrm{Mbit} / \mathrm{s}$ part circuit, October 2006

EU weighted average $2 \mathrm{Km}: 334 €, 5 \mathrm{Km}: 367 €$

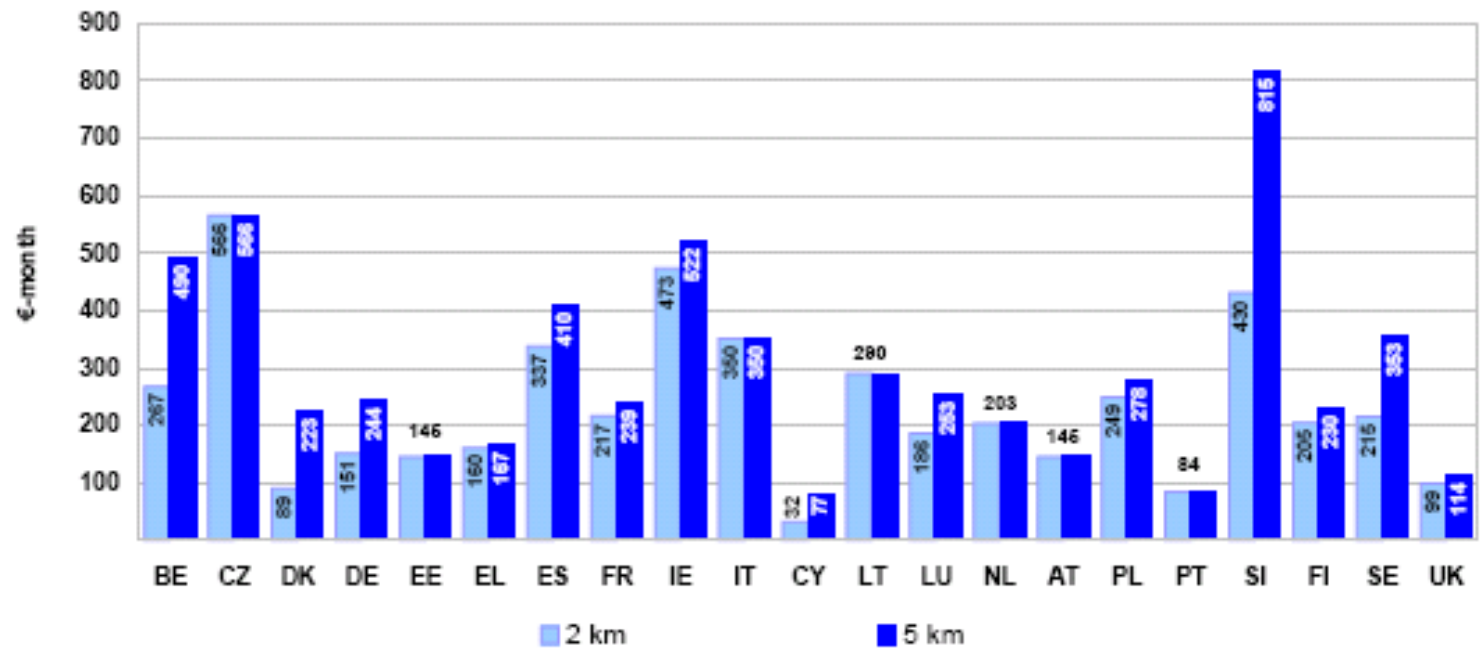

${ }^{5}$ European Commission (2008), except for leased line part circuit data, only available in this format from European Commission (2007b).

${ }^{6}$ Where wholesale broadband offerings are concerned, the access prices are underpinned by full unbundling or shared access services to provide the broadband access offer. 
Figure 3

Prices per full unbundled loop - Monthly rental EU average Oct. 2007: 9,52€

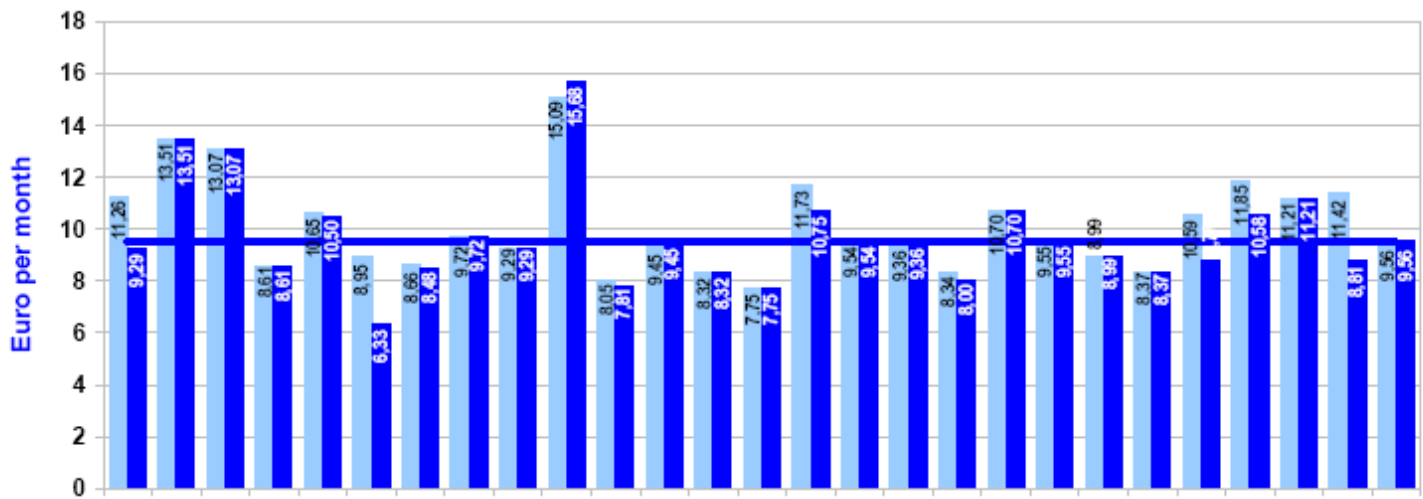

BE BG CZ DK DE EE EL ES FR IE IT CY LV LT LU HU MT NL AT PL PT RO SI SK FI SE UK

October 2006

October 2007

_EU average Oct. 2007

Figure 4

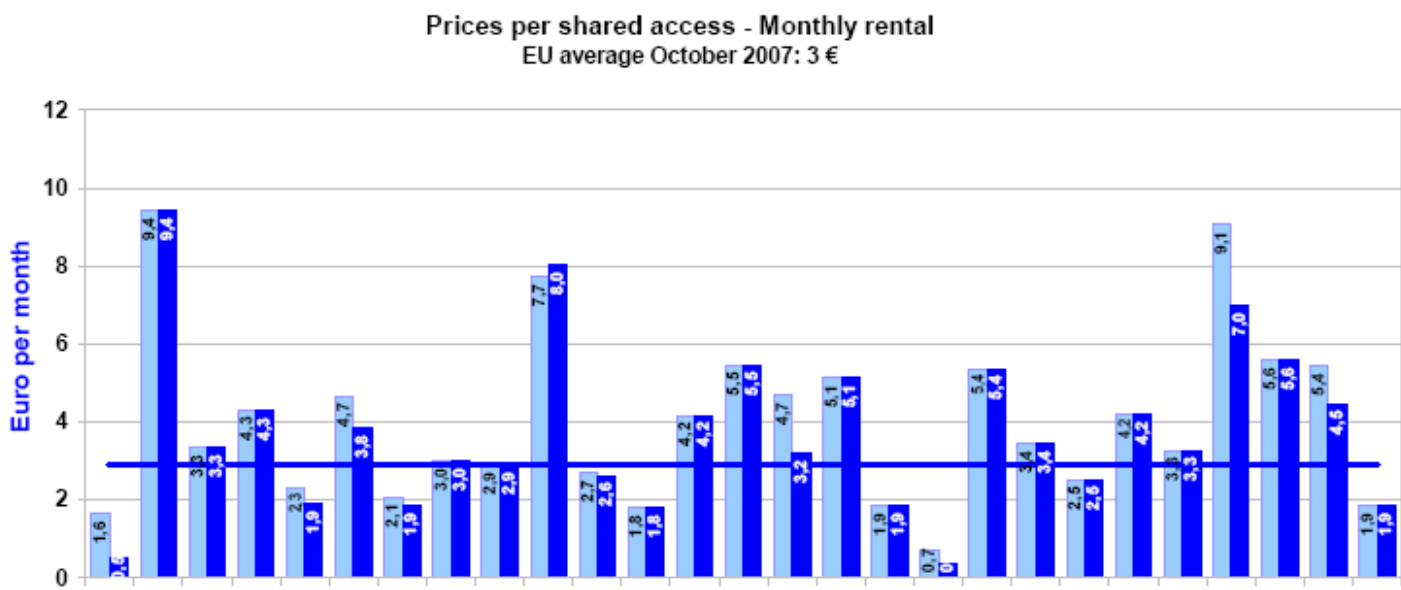

BE BG CZ DK DE EE EL ES FR IE IT CY LV LT LU HU MT NL AT PL PT RO SI SK FI SE UK 
These access products, which are typically subject to price regulation and access obligations, represent the main non-traded inputs in the provision of telecoms services to the major classes of end users, including large corporate customers (through private circuits) and SOHO / SME business customers, as well as residential customers (via LLU and shared access to support wholesale broadband offerings). ${ }^{7}$ In particular, in the context of this paper, such services are a central non-traded input in the provision of value-added telecoms services to corporate clients and where the issues associated with cross-border trade and comparative advantage are of particular relevance.

It is clear that the detriment associated with imperfect - or inappropriately absent - regulation will depend upon two factors, namely: (i) the level of the 'tariff' - in this case the extent to which regulators, as a result of information asymmetry or transitional factors or for less respectable reasons such as capture, allow prices to exceed costs for the non-traded input; and (ii) the proportion of the value added represented by that imperfectly regulated input.

Whilst a detailed cross-country comparison of unit costs and prices is beyond the scope of this paper, we can provide broad illustration of price-cost comparisons by taking lowest prices as a rough proxy for cost-based prices. ${ }^{8}$ So, by way of example, a comparison of EU average prices to, say, the average of the lowest three rates for the access products discussed above - by way of a cost proxy - yield the following illustrative 'mark-ups' of price over 'cost':

\footnotetext{
${ }^{7}$ These correspond to the categories of customers identified in Section 1.

${ }^{8}$ Such an approach has been used in the past by the European Commission in establishing 'best practice' interconnection rates using benchmark price data across member states. This analysis does not represent in any way a robust cross-country benchmarking exercise, which would seek to normalize for country-specific factors; it serves merely, with the graphs, to highlight the material differences in prices of key access services across member states.
} 
Table 1

\begin{tabular}{|l|c|c|c|}
\hline Euros/month & $\begin{array}{c}\text { [1] } \\
\text { EU weighted average }\end{array}$ & $\begin{array}{c}\text { [2] } \\
\text { Lowest 3 average }\end{array}$ & $\begin{array}{c}\text { [3] = [1] / [2] -1 } \\
\text { Implied excessive price }\end{array}$ \\
\hline 2km local end & 334.0 & 68.3 & $389 \%$ \\
5km local end & 367.0 & 91.7 & $300 \%$ \\
Full LLU & 9.5 & 7.3 & $30 \%$ \\
Shared access & 3.0 & 0.9 & $233 \%$ \\
\hline
\end{tabular}

Even adjusting for country-specific factors - such as differences in factor input costs and network cost drivers (such as population density) - there are clearly material differences in unit prices for comparable services across the sample set. These differences may result from the above factors, or indeed be because NRAs have yet to grapple with the market failure at hand, with this being of particular concern in countries recently having joined the EU. This suggests prices differ materially from cost and that - assuming over-regulation is avoided and that NRAs err on the side of caution - price are, on average, above the unit cost of service provision (or, to use the phraseology above, that regulators 'buy' private information to address information asymmetries in respect of operators’ cost).

Furthermore, whilst consideration of prices - and specifically the extent to which prices are consistently set with reference to the underlying costs of efficient service provision - is of importance, it is also necessary to consider the extent to which access is not provided at all, in addition to whether it is provided at the right price. As noted above, European NRAs have available to them the remedy of mandating access, and hence have the ability to tackle the most obvious or blatant attempts by SMP operators to foreclose competition through such means. However, more subtle - and more pervasive - is an approach of non-cooperation and non-price discrimination by the incumbent operator, thereby favouring its own downstream operations to the detriment of its competitors). Such actions can include delay in service provision or the 
quality of service and delay in ordering, processing and billing and can result in, effectively, the inability to provide an effective service for existing and prospective service providers. ${ }^{9}$

However, in addition to the existence of such anti-competitive practices, there also exist examples of proposed regulatory intervention which explicitly allow for such outcomes. An example is the ongoing debate concerning limiting the degree of access which competitors should be entitled to have to NGN, in the interest of ensuring that they are built earlier than would otherwise be the case.

Whilst the varied and often bespoke nature of corporate value-added services does not easily allow for an assessment of the proportion of value-added accounted for by the non-traded services referred to above, it is a reasonable assumption that they represent a material proportion of the total cost of service.

Thus, combining these two likely characteristics - an excessive regulated (or indeed inappropriately unregulated) price impacting a significant proportion of the total value added we can identify a potential risk that inefficient or absent regulatory intervention can result in the establishment of a significant barrier to trade. By way of illustration, taking the ratio of prices to (rough proxies for) costs for access services in the table above, and assuming such services account for, say, $30 \%$ of total value added for corporate services, then the 'efficiency advantage' on the traded activity which a foreign competitor would have to exhibit in order to remain competitive is as shown in table 2 below. For example, where a competitor was obliged to

\footnotetext{
${ }^{9}$ Such practices, whilst nothing new, have come to the fore in the context of broadband penetration and the access of LLU services by competing operators. Ofcom, the UK NRA, considered this matter of such significance that it has worked with BT to establish a framework of operational separation in order that BT's access business (now branded Openreach) is subject to an incentive to provide access of fair and equal terms to BT and others, and other regulatory bodies are following suit.
} 
purchase a shared access line, accounting for $30 \%$ of total service costs, at 2.3 times the cost at which it was self-supplied to the incumbent, the competitor would have to be twice as efficient in providing the services which make up the remaining $70 \%$ of costs.

Table 2

\begin{tabular}{|l|c|c|c|}
\hline Euros/month & $\begin{array}{c}\text { [3] } \\
\text { Implied tariff }\end{array}$ & $\begin{array}{c}\text { [4] } \\
\text { Proportion of } \\
\text { value added }\end{array}$ & $\begin{array}{c}\text { [5] = ([3] x [4] / (1- [4]) } \\
\text { Required efficiency } \\
\text { advantage }\end{array}$ \\
\hline 2km local end & 3.9 & $30 \%$ & 1.67 \\
$5 \mathrm{~km}$ local end & 3.0 & $30 \%$ & 1.29 \\
Full LLU & 0.3 & $30 \%$ & 0.12 \\
Shared access & 2.3 & $30 \%$ & 1.00 \\
\hline
\end{tabular}

This is just arithmetic, but the European Commission's own assessment of the timeliness and consistency of regulatory measures across Member States identifies concerns in this regard:

'Indeed, in a number of Member States there have been significant delays in the practical implementation of remedies, as well as divergence in the nature of the remedies chosen following completion of the market analyses and findings of significant market power (SMP). These are key factors that in practice have restrained the framework from exercising its full effect.'

Further:

'... the Commission's report ... found that, in a number of cases, the solutions which national regulators impose in order to remedy a lack of competition vary considerably, leading to the danger of a fragmentation of the internal telecoms market to the detriment of consumers and operators with pan-European business activities.' 
Such observations therefore present both immediate and longer-lasting effects. In the near term, inconsistency and inefficiency in regulatory policy potentially limits both domestic competition and the extent to which cross-border trade across European member states can be used to exploit comparative advantage in order to maximise productive output and economic growth. Further, in the longer term, under-consumption of telecommunications services - resulting from prices too high or lack of supply - may have a detrimental effect in incentives to invest in NGNs. Indeed, this therefore risks a self-reinforcing negative effect: lower demand for telecoms services and, by extension, value added services which can be best provided over NGNs potentially results in a lower investment in NGNs than would other be the case, thereby restricting the extent to which the lower cost characteristics of NGNs can be used to exploit country- and region-specific comparative advantage to the benefit of growth in economic output.

It is reasonable to ask what the consequences of the loss of trade might be. We attempt to make an 'order of magnitude' calculation here. ${ }^{10}$ It is carried out by distinguishing two effects: a 'demand-side' effect relating to the quality of service, capturing the greater willingness to pay of customers for seamless and higher quality services, and a 'supply-side' effect associated with both more competition in the supply of the service, and the exploitation of comparative advantage through trade in services. These two effects are illustrated in Figure 5.

\footnotetext{
${ }^{10}$ We are grateful to Dr Julian Tice for undertaking the calculations presented here.
} 
Figure 5 The supply-and demand-side gains from trade permitted by harmonisation

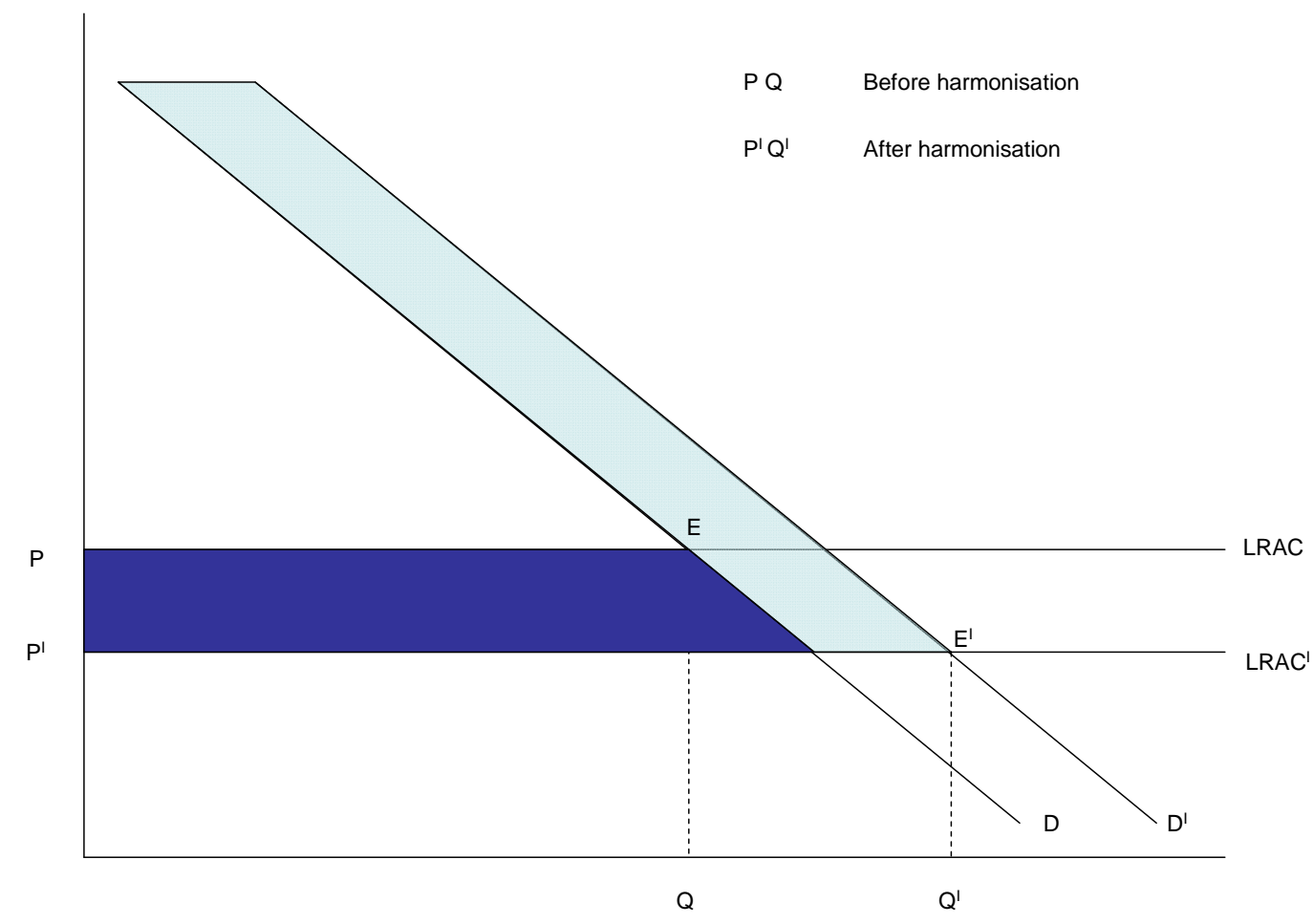

For the purposes of the calculation, we assume a price elasticity of demand of -0.9 . Then if willingness to pay rises by $5 \%$ and $\operatorname{costs}^{11}$ fall by $7.5 \%$, user surplus increases by $8 \%$, which, given the particular assumptions made here, amounts to $24 \%$ of expenditure ${ }^{12}$. Table 2 below provides some basic sensitivity analysis showing how user surplus gains change with increasing willingness to pay and falling cost levels.

\footnotetext{
${ }^{11}$ Defined as Long Run Average Costs, LRAC.

${ }^{12}$ These magnitudes are based in part upon the results of a questionnaire to which we have had access which was administered by INTUG, a business consumers' representative group.
} 


\section{Table 3: Illustrative user surplus gains from unified markets}

Greater Willingness to Pay

\begin{tabular}{|l|c|c|c|c|c|}
\cline { 2 - 6 } $\begin{array}{l}\text { Cost Reduction } \\
\text { (Supply Side) }\end{array}$ & $7,50 \%$ & $8 \%$ & $10 \%$ & $20 \%$ & $30 \%$ \\
\cline { 2 - 6 } & $12,50 \%$ & $9 \%$ & $14 \%$ & $23 \%$ & $33 \%$ \\
\hline \multirow{4}{*}{$25 \%$} & $14 \%$ & $20 \%$ & $30 \%$ & $35 \%$ \\
\cline { 2 - 6 } & $37,50 \%$ & $20 \%$ & $26 \%$ & $37 \%$ & $48 \%$ \\
\hline
\end{tabular}

To derive an order-of-magnitude estimate of what these numbers might entail, consider the following: in the EU in 2006, revenues from fixed and mobile telecommunications services amounted to some 300 billion euros. Suppose one-fifth of these fall into the category of services subject to or supporting gains from cross-border trade. Then the above estimate implies a gain in user surplus equal to something of the order of 15 billion euros per annum.

\section{Possible institutional reforms}

Underlying this paper are two propositions: firstly that the 'death of distance' is changing in a radical fashion the scope for trade (in the sense of cross-border trade, not Foreign Direct Investment, FDI) in telecommunications services and other services which they enable; secondly, that the limitations of regulation in the United States of Europe are preventing the benefits of such trade from being realised, whereas they are realised in the United States of America.

We have illustrated the proposition by looking at one marketplace in particular: that for telecommunications services provided to corporate customers, typically multinational companies. But we are aware that other services which rely on telecommunications services, such as payment systems or off-shore gambling will raise similar issues. 
Trade in such services will yield the classic benefits from comparative advantage and specialisation, lower prices and differential services. However, regulatory failures can prevent the realisation of these gains. The illustrative calculation above shows that they might be significant in Europe. This suggests, in the first instance, that regulators must be armed with the right information upon which to make decisions, both about what should and should not be regulated and, where intervention is necessary, its appropriate form, stringency and longevity. It also suggests that regulators must be sufficiently skilled to use this information in the right way, with this potentially being a particular challenge in those countries which have recently joined the EU. These points are particularly important in a world of Next Generation Networks, where large sunk investments are being considered, and supply-side (e.g. cost structure) and demand-side dynamics pose significant uncertainties.

However, our main conclusion is that European regulators should be more alive to the new possibilities and take the necessary steps to allow the emergence of genuinely international trade, in the first instance at least, in pan-European markets. So doing has the opportunity to unlock significant benefits accruing from the exploitation of country- or region-specific comparative advantage across the European Union.

What institutional reforms to European regulation would have this effect? ${ }^{13}$ The three stages required of regulators in implementing the European framework were noted in Section 4 above: market definition, market analysis and remedies if SMP is found. The NRAs' conclusions with respect to the first two are subject to a power of veto by the European Commission - a power

\footnotetext{
${ }^{13}$ For reasons set out above, we confine ourselves here to this form of amendment of the present system, and do not discuss the fuller application of international trade law.
} 
which they have utilised, or the threat of which has caused an NRA to withdraw its notification, on a dozen or so occasions, out of many hundreds of examples. But this under-estimates the effect of the power, since almost all NRAs seek pre-notification meetings with the Commission, the effect of which, in many cases, is to cause amendments to the actual notification. However, the same power of veto does not apply to remedies, even though the Commission often comments on them. This division of labour emerged as a compromise when the regulatory regime was developed in 2002. The NRAs undertook work within the framework European Regulators' Group, or ERG (the ‘college’ of NRAs) to achieve consistency on remedies (ERG 2003).

When the Commission published its proposals for revisions in 2007, they included a proposal to strengthen its own supervision of remedies, noting that some commentators were asking 'for a stronger role for the Commission in order to avoid a "lowest common denominator" approach, seen by some as inherent in a regulatory mechanism that essentially relies on consensus among 27 NRAs'. The Commission also proposed the creation of an independent European Electronic Communications Market Authority to advise it on matters relating to the single market, and to provide some sort of for its interventions on remedies. (European Commission 2007a, pp. 9-10).

These proposals elicited significant opposition from the NRAs and Member State governments, as well as amendment by the European Parliament. As a result, it is unlikely that the Commission will get a veto on remedies. It is more likely, however, that some version of the independent authority or a strengthened ERG will exercise a greater degree of control over them. This might involve a greater use of benchmarking, which could lead to a greater degree of convergence in the currently diverse numerical values of access prices analysed in section 3 above. However, it is also necessary that any greater coordination of regulation across member states avoids the pitfalls associated with consistency for consistency's sake - successful regulatory policy must reflect the 
specificities and idiosyncracies of individual markets and countries, and keep the principle of proportionality at the heart of decision-making.

Given the complexity and multi-dimensional nature of remedies, this may be all that is practicable. As a result, the barriers to trade identified above are likely to persist, but to operate at a lower level. But even this modest improvement can benefit large corporate customers.

\section{References}

Basalisco, Bruno et al. (2007) The Economic Benefit from Providing Business with Competitive Electronic Communications Services, BT.

ERG (2003), ERG Common Position on the approach to Appropriate remedies in the new regulatory framework, European Regulators Group, 2003.

European commission (2007a), press release, 27 June.

European Commission (2007b), $12^{\text {th }}$ Report on the Implementation of the Telecommunications Regulatory Package - 2006.

European Commission (2007c), Report on the outcome of the Review of the EU regulatory framework for electronic communications networks and services in accordance with Directive 2002/21/EC and Summary of the 2007 Reform Proposals. COM(2007) 695 final.

European Commission (2008), $13^{\text {th }}$ Report on the Implementation of the telecommunications Regulatory Package- 2007.

GATS (1994), The General Agreement on Trade in Services in Related Instruments.

Gordon, R.M. (2004) Why was Europe left at the station when the American productivity locomotive departed? NBER Working Paper 10661.

Kariyawasam, Rohan (2007) 'International communications', in Andrew T Guzman and Alan O Sykes (eds) Research Handbook in International Economic Law, Edward Elgar, Cheltenham, UK.

Manual (2007) Manual on Statistics of International Trade in Services, UN et al, Geneva.

Martimort, David and Thierry Verdier (2006) Domestic Regulation, Asymmetric Information and the Pattern of International Trade, IDEI Discussion Paper, Toulouse. 
OECD (2007b) Communications Outlook, Paris, July. 


\section{CESifo Working Paper Series}

for full list see www.cesifo-group.org/wp

(address: Poschingerstr. 5, 81679 Munich, Germany, office@cesifo.de)

2617 Axel Dreher, Peter Nunnenkamp, Hannes Öhler and Johannes Weisser, Acting Autonomously or Mimicking the State and Peers? A Panel Tobit Analysis of Financial Dependence and Aid Allocation by Swiss NGOs, April 2009

2618 Guglielmo Maria Caporale, Roman Matousek and Chris Stewart, Rating Assignments: Lessons from International Banks, April 2009

2619 Paul Belleflamme and Martin Peitz, Asymmetric Information and Overinvestment in Quality, April 2009

2620 Thomas Dohmen, Armin Falk, David Huffman and Uwe Sunde, Are Risk Aversion and Impatience Related to Cognitive Ability?, April 2009

2621 Yin-Wong Cheung and Xingwang Qian, The Empirics of China's Outward Direct Investment, April 2009

2622 Frédérique Bec and Christian Gollier, Assets Returns Volatility and Investment Horizon: The French Case, April 2009

2623 Ronnie Schöb and Marcel Thum, Asymmetric Information Renders Minimum Wages Less Harmful, April 2009

2624 Martin Ruf and Alfons J. Weichenrieder, The Taxation of Passive Foreign Investment Lessons from German Experience, April 2009

2625 Yao Li, Borders and Distance in Knowledge Spillovers: Dying over Time or Dying with Age? - Evidence from Patent Citations, April 2009

2626 Jim Malley and Ulrich Woitek, Technology Shocks and Aggregate Fluctuations in an Estimated Hybrid RBC Model, April 2009

2627 Jin Cao and Gerhard Illing, Endogenous Systemic Liquidity Risk, April 2009

2628 Thiess Buettner and Bjoern Kauder, Revenue Forecasting Practices: Differences across Countries and Consequences for Forecasting Performance, April 2009

2629 Håkan Selin, The Rise in Female Employment and the Role of Tax Incentives - An Empirical Analysis of the Swedish Individual Tax Reform of 1971, April 2009

2630 Nick Johnstone and Ivan Hascic, Environmental Policy Design and the Fragmentation of International Markets for Innovation, April 2009

2631 Spiros Bougheas, Richard Kneller and Raymond Riezman, Optimal Education Policies and Comparative Advantage, April 2009 
2632 Jay Pil Choi and Heiko Gerlach, Multi-Market Collusion with Demand Linkages and Antitrust Enforcement, April 2009

2633 Thor O. Thoresen, Income Mobility of Owners of Small Businesses when Boundaries between Occupations are Vague, April 2009

2634 Guido Schwerdt and Amelie C. Wuppermann, Is Traditional Teaching really all that Bad? A Within-Student Between-Subject Approach, April 2009

2635 Kurt R. Brekke, Luigi Siciliani and Odd Rune Straume, Hospital Competition and Quality with Regulated Prices, April 2009

2636 Peter Diamond, Taxes and Pensions, April 2009

2637 Shoshana Grossbard, How "Chicagoan” are Gary Becker's Economic Models of Marriage?, May 2009

2638 Roland Strausz, Regulatory Risk under Optimal Incentive Regulation, May 2009

2639 Holger Zemanek, Ansgar Belke and Gunther Schnabl, Current Account Imbalances and Structural Adjustment in the Euro Area: How to Rebalance Competitiveness, May 2009

2640 Harald Hau and Marcel Thum, Subprime Crisis and Board (In-)Competence: Private vs. Public Banks in Germany, May 2009

2641 Martin Halla, Mario Lackner and Friedrich G. Schneider, An Empirical Analysis of the Dynamics of the Welfare State: The Case of Benefit Morale, May 2009

2642 Balázs Égert, Infrastructure Investment in Network Industries: The Role of Incentive Regulation and Regulatory Independence, May 2009

2643 Christian Gollier, Expected Net Present Value, Expected Net Future Value, and the Ramsey Rule, May 2009

2644 Sören Blomquist and Håkan Selin, Hourly Wage Rate and Taxable Labor Income Responsiveness to Changes in Marginal Tax Rates, May 2009

2645 Dominique Demougin, Oliver Fabel and Christian Thomann, Implicit vs. Explicit Incentives: Theory and a Case Study, May 2009

2646 Francesco C. Billari and Vincenzo Galasso, What Explains Fertility? Evidence from Italian Pension Reforms, May 2009

2647 Kjell Arne Brekke, Karen Evelyn Hauge, Jo Thori Lind and Karine Nyborg, Playing with the Good Guys - A Public Good Game with Endogenous Group Formation, May 2009

2648 Guglielmo Maria Caporale and Luis A. Gil-Alana, Multi-Factor Gegenbauer Processes and European Inflation Rates, May 2009 
2649 Henning Bohn, A Static Model for Voting on Social Security, May 2009

2650 Markus Haavio and Kaisa Kotakorpi, The Political Economy of Sin Taxes, May 2009

2651 Augusto de la Torre, María Soledad Martínez Pería and Sergio L. Schmukler, Drivers and Obstacles to Banking SMEs: The Role of Competition and the Institutional Framework, May 2009

2652 Tobias Lindhe and Jan Södersten, Dividend Taxation, Share Repurchases and the Equity Trap, May 2009

2653 Assaf Razin and Edith Sand, Migration-Regime Liberalization and Social Security: Political-Economy Effect, May 2009

2654 Yin-Wong Cheung and Hiro Ito, A Cross-Country Empirical Analysis of International Reserves, May 2009

2655 Bart Cockx and Bruno Van der Linden, Flexicurity in Belgium. A Proposal Based on Economic Principles, May 2009

2656 Michael Melvin, Lukas Menkhoff and Maik Schmeling, Exchange Rate Management in Emerging Markets: Intervention via an Electronic Limit Order Book, May 2009

2657 Susanne Neckermann, Reto Cueni and Bruno S. Frey, What is an Award Worth? An Econometric Assessment of the Impact of Awards on Employee Performance, May 2009

2658 Steven Brakman, Harry Garretsen and Charles van Marrewijk, Economic Geography within and between European Nations: The Role of Market Potential and Density across Space and Time, May 2009

2659 Giovanni Facchini and Cecilia Testa, Reforming Legislatures: Is one House better than two?, May 2009

2660 Carsten Kowalczyk and Raymond Riezman, Trade Agreements, May 2009

2661 Oliver Falck, Stephan Heblich and Elke Luedemann, Identity and Entrepreneurship, May 2009

2662 Christian Lessmann and Gunther Markwardt, One Size Fits All? Decentralization, Corruption, and the Monitoring of Bureaucrats, May 2009

2663 Felix Bierbrauer, On the Legitimacy of Coercion for the Financing of Public Goods, May 2009

2664 Alessandro Cigno, Agency in Family Policy: A Survey, May 2009

2665 Claudia M. Buch and Christian Pierdzioch, Low Skill but High Volatility?, May 2009 
2666 Hendrik Jürges, Kerstin Schneider, Martin Senkbeil and Claus H. Carstensen, Assessment Drives Learning: The Effect of Central Exit Exams on Curricular Knowledge and Mathematical Literacy, June 2009

2667 Eric A. Hanushek and Ludger Woessmann, Schooling, Cognitive Skills, and the Latin American Growth Puzzle, June 2009

2668 Ourania Karakosta, Christos Kotsogiannis and Miguel-Angel Lopez-Garcia, Does Indirect Tax Harmonization Deliver Pareto Improvements in the Presence of Global Public Goods?, June 2009

2669 Aleksandra Riedl and Silvia Rocha-Akis, Testing the Tax Competition Theory: How Elastic are National Tax Bases in OECD Countries?, June 2009

2670 Dominique Demougin and Carsten Helm, Incentive Contracts and Efficient Unemployment Benefits, June 2009

2671 Guglielmo Maria Caporale and Luis A. Gil-Alana, Long Memory in US Real Output per Capita, June 2009

2672 Jim Malley and Ulrich Woitek, Productivity Shocks and Aggregate Cycles in an Estimated Endogenous Growth Model, June 2009

2673 Vivek Ghosal, Business Strategy and Firm Reorganization under Changing Market Conditions, June 2009

2674 Francesco Menoncin and Paolo M. Panteghini, Retrospective Capital Gains Taxation in the Real World, June 2009

2675 Thomas Hemmelgarn and Gaëtan Nicodème, Tax Co-ordination in Europe: Assessing the First Years of the EU-Savings Taxation Directive, June 2009

2676 Oliver Himmler, The Effects of School Competition on Academic Achievement and Grading Standards, June 2009

2677 Rolf Golombek and Michael Hoel, International Cooperation on Climate-Friendly Technologies, June 2009

2678 Martin Cave and Matthew Corkery, Regulation and Barriers to Trade in Telecommunications Services in the European Union, June 2009 